\title{
PRICE AS AN INTEGRATED MARKETING COMMUNICATION TOOL IN PROMOTING THE CONSUMPTION OF SUSTAINABLE PRODUCTS
}

\author{
Santa Bormane ${ }^{1}$
}

\begin{abstract}
There are favourable conditions for the development of sustainable marketing in Latvia. In order to take advantage of this, businesses need to conduct market research on the need and demand for sustainable products and draw up a marketing strategy encompassing all the marketing mix elements serving the People, Planet, and Profit. Businesses need to create a well-thought approach, a sustainable product assortment and promotion and selling activities in line with sustainability conditions. The consumers of nowadays are very sensitive to any price changes, and businesses may use price changes as an IMC (integrated marketing communication) tool in communication with their consumers to help not only sell or promote new products, but also boost the sales of healthy, ecological, domestic manufactured products.

The goal of the research is to study and assess the role of price as an integrated marketing communication tool for sustainability in the context of demand. The subject of the research is price as a set of IMC tools, and the object of research are the price tools for the sustainable development of food retail chains.

In order to accomplish the goal and objectives of the research, the author used the results of previous studies and the following quantitative and qualitative methods of economic research: survey, comparison, and grouping. The research is based on scientific papers published by Latvian and foreign scholars, general and scientific literature, and periodicals. Within the research there an assessment was conducted, a market investigation, a comparative analysis, as well as a survey of leading specialists from Latvian food retail chains, with the MS Excel software used for data processing and analysis.

The research confirmed the hypothesis that price changes as an IMC tool and the use therefore may positively affect the buyer's market behaviour and foster the consumption of sustainable, ecological, domestic manufactured products. The results of the research are of both theoretical and practical value.
\end{abstract}

JEL Classification Numbers: M31; DOI: http://dx.doi.org/10.12955/cbup.v6.1134

Keywords: price, sustainability, sustainable marketing, integrated marketing communications, integrated marketing communication tools

\section{Introduction}

The consumers of nowadays are very sensitive to any price changes, and businesses may use price changes as an IMC (integrated marketing communication) tool in communication with their consumers to help not only sell or promote new products, but also boost the sales of healthy, ecological, domestic manufactured products.

The goal of the research is to study and assess the role of price as an integrated marketing communication (IMC) tool for sustainability in the context of demand. The subject of the research is price as a set of IMC tools, and the object of research are price tools for a sustainable development of food retail chains.

In order to accomplish the goal and objectives of the research, the author used the results of previous studies and the following quantitative and qualitative methods of economic research: survey, comparison, and grouping. The research is based on scientific papers published by Latvian and foreign scholars, general and scientific literature, and periodicals. Within the research there was conducted an assessment, a market investigation, a comparative analysis, as well as a survey of leading specialists from Latvian food retail chains, with the MS Excel software used for data processing and analysis.

\section{Price as an IMC Tool in Communication with Consumers}

A precondition of sustainability is not only action, cooperation and authorities' willingness to protect nature and natural resources, but also meeting economic needs and cultivation of economic opportunities. Furthermore, as pointed out by Thiele (2013), one must also meet social needs and create a fair relationship among different social groups. As "green" as a business may be, it is not sustainable if unable to gain profit and pay its employees for work. The author agrees that one of the goals of a business is to gain profit, which is to the benefit of the business itself as well as the state, the public, and the region where the business resides. However, the author would like to stress that profit must not be the leitmotiv of a business. This is supported, for instance, by Mohammed (2015) who refers to the World Economic Forum report on income inequality in the world; the 2014 study by the Organisation for the Economic Cooperation and Development (OECD) on the impact of income

\footnotetext{
${ }^{1}$ University of Latvia, Faculty of Business, Economics and Management, santa.bormane@gmail.com
} 
inequality upon GDP growth figures (OECD, 2014); as well as Meyer et al. (2014) who believe that income inequality falls right within the range of sustainability challenges.

It makes sense that people seek the highest quality for the lowest price, yet the question remains at what expense this lowest price comes. Usually everything begins with the purchase of raw materials, followed by production, and from a business perspective the logical venue of production is one where the unit cost is the lowest. The choice tends to fall in favour of Eastern countries - China, India etc. Quite often, when purchasing a product, the consumer is not even aware that, for instance, the workers involved in its production work beyond acceptable hours, their salary only covers the bare minimum of basic needs, and the labour conditions are sometimes dangerous to health and even life.

Costs may play a key role in consumers' final decisions on purchases, as there are groups of people described as "hypersensitive" to price changes, especially in online markets (Degeratu at al., 2000). The research by Mhurchu et al. (2010) found out that sales of healthy products increased by $10 \%$ when they were on discount. In the survey by Di Vita et al. (2013), cost was proved to be in close relation with quality, as it was expected to, and the assessment of consumer purchasing decisions on different types of olive oil (conventional and organic) showed that the highest influence factor was price and area of origin". Furthermore, "cost, availability and preparation time are limiting factors" in the consumption of food products (Almli et al., 2011). Consumers tend to perceive biological products as high-quality and more expensive than traditional products (Vlontzos et al., 2016).

Competitors, too, may run deliberate price lowering campaigns by altering or misconstruing the message on the product, service, brand or company (Calonius, 1989). However, as pointed out by Brassington and Pettitt (2006), research has showed that consumers, when given the option of a biologically grown and ecologically clean product that costs more, struggle to make a connection between their individual buying decision and influence on the global situation. It will, of course, take time for the society to adapt and achieve balance, but there is evidence that, if no changes are made, the long-term adverse effect on both the environment and the society will be inevitable.

\begin{tabular}{|l|l|l|l|l|}
\hline Figure 1: Distribution of employees in Latvia by income, annual average, \% \\
\hline
\end{tabular}

A sustainably developed country is underpinned by a stable middle class of people. Hence, one must definitely consider the distribution of income among classes. According to the CSB data (see Figure 1), at the beginning of the reporting period in 2012 more than half or approximately 53\% of Latvia's population received a salary of up to 500 euros per month (Central Statistical Bureau of Latvia).

From a sustainability perspective, this does not raise much hope in terms of a strong middle class with stable income for meeting basic needs, yet, on a positive note, the trend appears to be diminishing. However, when reviewing this data, one has to consider that the income shown includes all gross income calculated for paid work, subject to individual income tax (Central Statistical Bureau of Latvia).

While the data suggests that people's income tends to increase, the CSB has also established an increase in the poverty risk threshold, setting it at 318 euros per month in 2015. According to the CSB, 
$21.8 \%$ of Latvia's population had a net income of less than 318 euros per month in 2015 and were thus exposed to poverty risk (Central Statistical Bureau of Latvia). The Gini coefficient, used as a measure of income inequality, has not changed much in Latvia - from $35.1 \%$ in 2010 to $34.5 \%$ in 2015, while the EU average in 2015 was $31 \%$ (Eurostat).

The problems faced by the Latvian tax policy and tax collection are outlined by the Head of the Monetary Policy Department at the Bank of Latvia, Rutkaste (Latvijas Avizze, 2016) who admits that, while the tax amount collected in Latvia is among the lowest in the EU, the tax burden for an honest taxpayer in Latvia is high. The expert adds that, despite the high tax burden, the tax collection amount against the gross domestic product in Latvia is low because of a high degree of grey economy.

The CSB does not collect information on Latvian-produced goods in shops, so, as pointed out by Lazdina and Skreija (2014), a 2014 study by Lursoft and surveys with the major Latvian retail chains have led to a conclusion that people in Latvia prefer Latvian-made products because the domestic producer better knows the people's wishes and tastes. The retail chain representatives surveyed claim that they try to include as many Latvian-made products as possible in their assortment and to reduce prices by creating and developing their private trademarks.

Another important aspect is the Latvian climate which makes, for instance, Latvian-grown vegetables, fruits and berries highly seasonal. While during the warm months of the year fresh fruits, vegetables and berries are available relatively cheaply, the winter months see much more limited supply and higher prices. Not only do the buyers suffer from this seasonality, but also the Latvian economy overall, as the money produced and earned in Latvia is spent on imported goods, which are used to satisfy demand. Imported products are priced lower, especially when purchased in bulk for production purposes, yet this is often to the detriment of product quality and the final consumer.

Reverting to the topic of the proportion of Latvian-made products in shops, the 2016 survey conducted by the Latvian Federation of Food Companies (LPUF) across the Baltic States reveals that in the case of Latvia a price difference of just a few cents would incline buyers towards import production. Just around $45 \%$ would certainly opt for Latvian products even if they cost more. Price is the main factor for people aged 45 to 54 and for those with a monthly income of 500 to 700 euros. Domestic products are regularly bought by people of middle and older generations (Sākas kampaņa "Karotīte...", 2016).

The author would like to suggest that the sales of domestic products could be fostered by reducing the VAT rate on domestically produced food, as has been done elsewhere in the EU. This would stimulate the economy, improve consumers' purchasing power, and make Latvian producers more competitive both domestically and on the EU scale. From a trader's viewpoint, this would contribute to a sustainable development of the local economy and society.

In the current age, sustainable marketing is aimed towards a sustainable development and a sustainable economy. In such an economy all environmental costs of production and consumption are merged (Peattie, 2001). This view incorporates ecological (environmental), social (equity) and financial (economic) sustainability (Savitz et al., 2006). According to Peattie (2001), sustainable economic development exposes marketing to major challenges when it comes to fair distribution of the costs and benefits of economic development across nations.

Hunt (2011) stresses the importance of the "green consumer" as a new market segment in sustainable marketing, as 1) the green consumer segment places a high value on protecting the environment; 2) not only consumers, but also firm owners and employees may be motivated to contribute financially to solving problematic issues of social development and the environment; 3) consumers may prefer products produced in a sustainable production process. For firms, in turn, a "green" production (incl. resources) may yield a competitive advantage. Sustainable marketing is also associated with the personal interests of a firm's employees, their behaviour and its compliance with the core principles of sustainable marketing. Consistent with the self-interest seeking dimension of human behaviour, superior financial performance is seen as the firm's primary objective, with larger and more successful firms (by financial figures) thus more likely to promote sustainable marketing than small businesses. On a general note, Hunt states that sustainable marketing is tied to sustainable development, while sustainable development is tied to the wealth of nations, and the wealth of nations is tied to economic growth (Hunt, 2011). This only enhances the development prospects, role and importance of sustainable marketing. The author's previous research, too, essentially confirmed that there are 
favourable conditions for the development of sustainable marketing in Latvia. In order to take advantage of this, businesses need to conduct market research on the need and demand for sustainable products and draw up a marketing strategy encompassing all the marketing mix elements serving the People, Planet, and Profit. The concept of sustainable marketing does not necessitate a cost increase in the marketing budget, but rather a well-through approach - the creation, promotion and sale of sustainable goods/services (packaging, price, delivery, transportation etc.) (Praude et al., 2012).

Based on the above and focusing on price as a key influence on consumers, the author finds that in the current market consumers are very sensitive to any price changes. Hence, price changes may be used as an IMC tool in communication with consumers, which may not only foster the consumption of traditional products and the entry of new products, but also promote the sales of healthy and ecological products etc. In this respect the author holds that consumers' desire and purchase may be influenced through the company's discount system, price level, sales promotion (incl. coupons, gifts for purchase) etc.

\section{A study of the impact of price-related integrated marketing communication tools upon demand}

At the beginning of the paper, the author put forward a hypothesis that price changes as an IMC tool and the use therefore may positively affect the buyer's market behaviour and foster the consumption of sustainable, ecological, domestic products. In order to confirm or reject the hypothesis, the author studied Latvian food retail chains with a view to assess the impact of price-related IMC tools upon demand. The author drew up a questionnaire and in 2017 conducted a survey of leading specialists from all Latvian food retail chains, with the MS Excel software used for data processing and analysis.

The experts were asked to rate the price-related IMC tools applied by the Latvian food retail chains and their impact upon demand, as well as whether in the next 3 years the companies intend to use price-related IMC tools for sustainability and how using those tools would affect demand at the retail chains, economic development, social responsibility, and environment preservation by the following scale: $\mathrm{N}$ - the sustainable marketing communication in question does not exist; -1 - the sustainable marketing communication in question reduces demand, its use will harm the economic and social development of the country and the preservation of the environment; 0 - the sustainable marketing communication in question does not affect demand, its use will not affect the economic and social development of the country; 1 - the sustainable marketing communication in question slightly increases demand, its use will have a positive effect on the economic and social development of the country and the preservation of the environment; 2 - the sustainable marketing communication in question substantially increases demand, its use will have a substantial positive effect on the economic and social development of the country and the preservation of the environment.

According to the results of the expert survey and the summary of ratings (see Figure 2), the author has visually represented the most popular price-related IMC tools applied by the Latvian food retail chains in their marketing strategy. As can be seen, they increase demand at the Latvian food retail chains and thus have a substantial impact on buyers' behaviour on the market. Figure 2 also shows that demand at retail chains is substantially increased by price-related IMC tools such as pricing policy, discount systems, price level, sales promotion activities related to price changes, as well as a retail chain's positioning on the market. Low proportion of discounted products, in turn, reduces demand, according to the experts. The author concurs with the experts' view that pricing policy as a price-related IMC tool affects demand, since pricing policy and price level substantially influences the company's market position, competitive prospects, target audience, overall sales figures etc. Hence, an appropriate pricing policy yields not only immediate economic benefits, but also a long-term effect.

The research shows that, in the context of sustainability with a focus on the development of the concept of sustainable marketing, the Latvian food retail chains should build their pricing policy for sustainability from the outset, envisaging discounts on ecological, Latvian-made products, and those with environmentally-friendly packaging. Last but not least, sales promotion activities, too, should first be conducted for ecological and Latvian-made products, which would then constitute a sustainable marketing strategy fostering the consumption of the said products. 

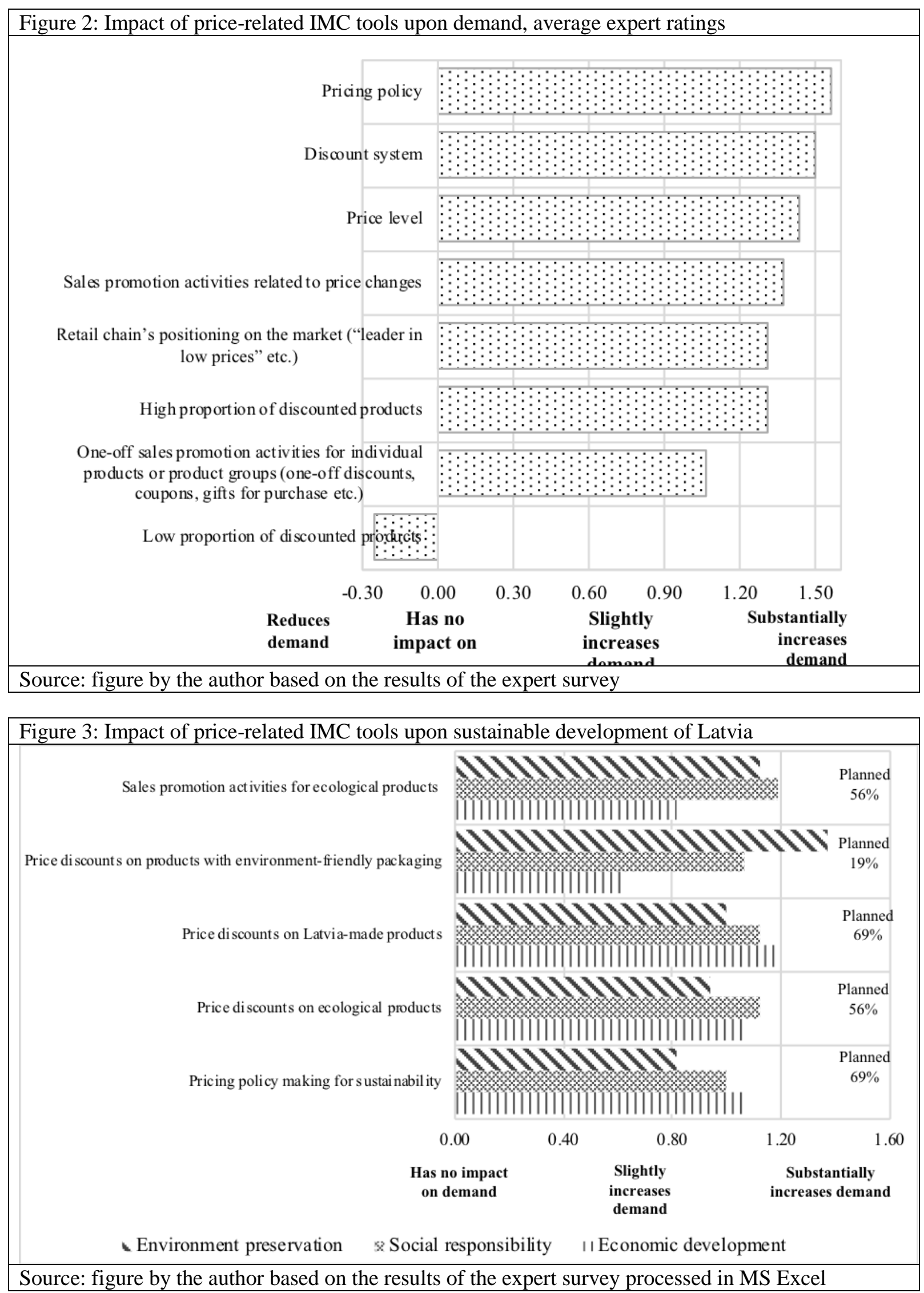

Vlontzos et al. (2018) studied the attitude of young Eastern European and Western European people (aged 18 to 30) towards the consumption of domestic and traditional products. The cost parameter was one of the factors introduced in the questionnaire. Rather surprisingly, in the Eastern European 
countries which face more financial hardships, people appear to be willing to pay more for quality products, especially traditional food products. Hence, businesses selling or producing such articles are more profitable in Eastern European countries. The author essentially agrees with the conclusion that for the consumers of nowadays price is one of the determining factors in buying decisions. Quite often price changes contribute to an increase - or a decrease - in a product's sales. The author believes that price discounts and sales promotion activities involving price changes is an effective IMC tool for sustainability aimed towards increasing the sales figures specifically for domestic products, boosting their consumption and the national economy.

The author has determined (see Figure 3) that demand at retail chains is slightly increased by such price-related IMC tools for sustainability as pricing policy making for sustainability, price discounts on ecological products, and price discounts on Latvia-made products. Price discounts on products with environment-friendly packaging and sales promotion activities for ecological products, in turn, are predominantly said to be absent from the marketing strategies of food retail chains. However, the expert opinions were mixed (with a variation range of 4 grades). The author thus concludes that price discounts on ecological products and Latvian-made products as an IMC tool for sustainability is an essential basis for the promotion of consumption of such products. The results of the study and the fact that businesses do not focus on sustainable, ecological, Latvian-made products in their marketing strategies suggest that these price-related IMC tools are perceived as relatively new and unproven.

Since these tools are not applied in marketing communication with consumers, it is impossible to measure the benefits from the use of specific IMC tools for sustainability. Still, the author maintains that by implementing these IMC tools for sustainability and applying them in marketing activities related to price discounts or gifts for purchases, with the inclusion of ecological products and their samples, businesses would not only enhance the recognition and consumption of the products themselves, but also create a new niche in building the loyalty of customers, specifically those buying ecological products.

\section{Conclusion}

The author recommends for businesses, in cooperation with ecological product manufacturers, to develop a marketing strategy where the food retail chain as an intermediary between the consumer and the producer receives partial support for sales promotion activities - gifts and samples (of, for instance, ecological tea or spices) for the retail chain to distribute to consumers for certain purchases of ecological products or volumes thereof. This would not only improve the recognition of those products, but also enable the producer to acquaint consumers with new products, building their consumption value and boosting their demand.

The author finds pricing policy making for sustainability and price discounts on ecological products to be the IMC tools for sustainability which businesses intend to use in their marketing strategies within the next 3 years (see Figure 3). This shows that businesses recognise price as a key factor in enhancing the consumption of ecological Latvian-made products. Through an appropriate pricing policy geared for sustainability it is possible to reach both short-term and long-term goals in terms of sales increase. For ecological, Latvian-made products and their consumption, price would be a key factor in raising demand. Since discounts and sales promotion activities typically take place as campaigns, these IMC tools for sustainability, merged and combined, could substantially improve the sales figures of food retail chains.

Concerning price discounts on products with environment-friendly packaging, it is curious that food retail chains do not intend to apply this IMC tool for sustainability in their marketing strategy within the next 3 years (see Figure 3). The author attributes this to the fact that retail chains include products in their assortment depending on the supply offered by producers. With the proportion of products with environmentally-friendly packaging being rather low as producers, like vendors and consumers, need to be educated on the importance of sustainability, retail chains cannot set this IMC tool for sustainability as a priority in their marketing strategy. Still, the author recommends for retail chains to include price discounts on products with environmentally-friendly packaging in their marketing strategy. Such a pricing policy, along with other planned price-related IMC tools for sustainability, would help preserve the environment and also secure assortment in the context of sustainability. The said recommendation by the author is based on the results of research - despite the businesses not 
intending to apply price discounts on products with environmentally-friendly packaging in their marketing strategy within the next 3 years, the experts have rated this price-related IMC tool for sustainability as beneficial to the economy, social responsibility, and the environment, especially in terms of environmental preservation.

The leading specialists from Latvian food retail chains have found all price-related IMC tools for sustainability to be conducive to Latvia's sustainability, especially price discounts on Latvian-made products. The author concludes that businesses realise that trading in domestic products may directly influence the national economy and an increased consumption of domestic products may positively contribute to public wellbeing. This would foster the consumption of products, the increase of production output of domestic businesses, new jobs, the availability of domestic production, and the state's competitiveness, the budget revenue from taxes etc.

\section{References}

Thiele, L. P., 2013. Sustainability. UK: Polity Press, p. 5

Mohammed, Outlook of the global agenda, 2015. Deepening income inequality, available from http://reports.weforum.org/outlook-global-agenda-2015/top-10-trends-of-2015/1-deepening-income-inequality/ [accessed on $07.02 .2017]$

OECD, 2014, Focus on Inequality and Growth - December 2014, available from http://www.oecd.org/els/soc/FocusInequality-and-Growth-2014.pdf [accessed on 07.02.2017]

Meyer, Kirby, 2014, Income inequality is a sustainable issue, Harward Business Review, available from https://hbr.org/2014/01/income-inequality-is-a-sustainability-issue-2 0 [accessed on 07.02.2017]

Degeratu, A.M.; Rangaswamy, A.;Wu, J. Consumer Choice Behavior in Online and Traditional Supermarkets: The Effects of Brand Name, Price, and Other Search Attributes. Int. J. Res. Mark. 2000, 17, 55-78.

Mhurchu, C.N.; Blakely, T.; Jiang, Y.; Eyles, H.C.; Rodgers, A. Effects of Price Discounts and Education on Supermarket Purchases. Am. J. Clin. Nutr. 2010, 3, 736-747.

Di Vita, G.; D’Amico, M.; La Via, G.; Caniglia, E. Quality Perception of PDO Extra-Virgin Olive Oil: Which Attributes Most Influence Italian Consumers? Agric. Econ. Rev. 2013, 14, 46-58.

Almli, V.L.; Verbeke, W.; Vanhonacker, F.; Næs, T.; Hersleth, M. General Image and Attribute Perceptions of Traditional Food in Six European Countries. Food Qual. Prefer. 2011, 22, 129-138.

Vlontzos, G.; Duquenne, M.N.; Niavis, S. Evaluating Consumer Beliefs for Traditional and Localized Foodstuff under Economic Stress. Int. J. Sustain. Agric. Manag. Inform. 2016, 2, 174-192.

Calonius, H., 1989, "Market communication in service marketing”, in Avlonitis, G.J., Papavasiliou, N.K. and Kouremeos, A.G. (Eds), Marketing Thought and Practice in the 1990s, Proceedings from the XVIIIth Annual Conference of the European Marketing Academy, Athens

Brassington, F., Pettitt, S., 2006. Principles of marketing (4th ed.). Essex: Pearson Education Limited, p. 23

Central Statistical Bureau of Latvia, Nabadzības riskam Latvijā pakḷauti 424 tūkstoši jeb 21,8\% iedzīvotāju, available from http://www.csb.gov.lv/notikumi/nabadzibas-riskam-latvija-paklauti-424-tukstosi-jeb-218-iedzivotaju-45823.html [accessed on 08.02.2017]

Central Statistical Bureau of Latvia, CSP informatīvais apskats par Darba n̄èmēju skaita sadalījumu pēc darba ienākumiem 2015.gadā, available from www.csb.gov.lv [accessed on 08.02.2017]

Eurostat. Gini coefficient of equivalised disposable income, available from http://appsso.eurostat.ec.europa.eu/nui/show.do?dataset=ilc_di12 [accessed on 08.02.2017]

Latvijas Avīze. Latvijā ir augsts nodokḷ slogs, 2016, available from http://www.la.lv/latvija-ir-augsts-nodoklu-slogs/ [accessed on 08.02.2017]

Lazdina, Skreija, Lursoft, (2014), Vietējie pārtikas tirgotāji sasparojas, available from: http://www.la.lv/vietejie-partikastirgotaji-sasparojas/ [accessed on 09.02.2017]

Sākas kampaṇa „,Karotīte vieno! Izvēlies vietējos produktus!”, 2016, available from: http://www.lpuf.lv/lv/sakas-kampanakarotite-vieno-izvelies-vietejos-produktus [08.02.2016]

Peattie, K., 2001, Towards sustainability: The third age of green marketing. The Marketing Review, 2(2), 129-146.

Savitz, A. W., \& Weber, K., 2006, The triple bottom line: How today's best-run companies are achieving economic, social and environmental success - and how you can too. New York: John Wiley.

Hunt, S., 2011, Sustainable marketing, equity, and economic growth: a resource-advantage, economic freedom approach, Journal of the Academy of Marketing Science is the property of Springer Science \& Business Media B.V., p 7-20

Praude., V., Bormane, S., 2012, Trends of development and possibilities of efficiency improvement in marketing communications, Humanities and Social Sciences Latvia, Latvijas Universitate, Volume 20, p 63-76

Vlontzos, G., Kyrgiakos, L., Duquenne, M.N., 2018, What Are the Main Drivers of Young Consumers Purchasing Traditional Food Products? European Field Research, Food Science Journal, p 16 